\title{
Novel galactonic acid-binding hexameric lectin from Hibiscus mutabilis seeds with antiproliferative and potent HIV-1 reverse transcriptase inhibitory activities
}

\author{
Sze Kwan Lam ${ }^{\bowtie}$ and Tzi Bun $\mathrm{Ng}^{凶}$ \\ School of Biomedical Sciences, Faculty of Medicine, The Chinese University of Hong Kong, Shatin, \\ New Territories, Hong Kong, China
}

Received: 05 June, 2009; revised: 05 October, 2009; accepted: 13 November, 2009

available on-line: 04 December, 2009

\begin{abstract}
A hexameric 150-kDa lectin was isolated from dried Hibiscus mutabilis seeds using a chromatographic protocol that involved ion exchange chromatography on SP-Sepharose, and gel filtration on Superdex 75 and Superdex 200. The lectin was not adsorbed on SP-Sepharose and was eluted from the Superdex 75 column in the void volume. It was eluted in the first peak from Superdex 200. It was strongly adsorbed on DEAE-cellulose and Q-Sepharose and could not be easily desorbed. The hemagglutinating activity of the lectin, which was stable at $\mathrm{pH} 4-7$ and up to $50^{\circ} \mathrm{C}$, could be inhibited by $25 \mathrm{mM}$ galactonic acid. This is the first report of a galactonic acid-binding lectin. It potently inhibited HIV-1 reverse transcriptase with an $\mathrm{IC}_{50}$ of $0.2 \mu \mathrm{M}$. It exhibited weak antiproliferative activity towards both hepatoma HepG 2 cells $(40 \%$ inhibition) and breast cancer MCF-7 cells (50\% inhibition) at $100 \mu \mathrm{M}$ concentration of the lectin. It did not inhibit mycelial growth of a number of fungi tested.
\end{abstract}

Keywords: Hibiscus mutabilis, hexameric lectin, galactonic acid

\section{INTRODUCTION}

Lectins are carbohydrate-binding proteins present in a diversity of organisms including humans, vertebrates and invertebrates, plants, and fungi (De Hoff et al., 2009; Jin et al., 2009). They display a host of biological activities such as antitumor (Lam et al., 2009), antifungal (Yan et al., 2005), and antiviral (Leung et al., 2008) activities. Based on their carbohydrate binding specificity they can be divided into (i) mannose binding, (ii) glucose and mannose binding, (iii) $\mathrm{N}$-acetylglucosamine binding, (iv) galactose binding, (v) sialic acid binding, (vi) fucose binding, etc.

Hibiscus mutabilis belongs to the family Malvaceae. It is commonly known as Confederate rose or cotton rosemallow. Only few publications about H. mutabilis were found in a PubMed search. An aqueous extract of $H$. mutabilis exerted anti-herpes simplex virus-II action (Zheng, 1989). H. mutabilis is one of the greening tree species planted in a polluted factory area in Shanghai (Yang et al., 2004). The benzene extract of its flowers did not markedly affect pregnancy (Kholkute et al., 1977). Pigments are found in H. mutabilis flowers (Yeh et al., 1958).

According to the Herbalist's Manual, H. mutabilis leaves aid detoxification, reduce swellings and alleviate pain. $H$. mutabilis leaves can be used to treat carbuncles, dermal swelling or inflammation, scalds, conjunctivitis, external and internal trauma and herpes zoster, its flowers to treat continuous menstrual flow and scalds, and its roots to treat skin ulcer. However, there is no information about its seeds.

In view of the paucity of information on $H$. mutabilis, especially with regard to its proteinaceous constituents, the present investigation was undertaken to isolate a lectin from its seeds. The lectin is multimeric and manifests highly potent HIV-1 re-

${ }^{\square}$ Corresponding author: Sze Kwan Lam: e-mail: lamszekwan@yahoo.com.hk; Tzi Bun Ng: e-mail: b021770@mailserv.cuhk. edu.hk; School of Biomedical Sciences, Faculty of Medicine, The Chinese University of Hong Kong, Shatin, New Territories, Hong Kong, China; phone: 852-2609 8031; fax: 852-2603 5123.

Abbreviations: SDS/PAGE, sodium dodecyl sulfate/polyacrylamide gel electrophoresis. 
verse transcriptase inhibitory activity and a unique sugar specificity. The results of the present study constitute an addition to the scanty literature on hexameric lectins which contrasts sharply with the voluminous data on lectins with a lower molecular mass and a smaller number of subunits.

\section{MATERIALS AND METHODS}

Purification of lectin. The seeds were authenticated by Professor Shiuying $\mathrm{Hu}$, Honorary Professor of Chinese Medicine, The Chinese University of Hong Kong, and deposited with the voucher number NG2009003 in Lab 302, Basic Medical Science Building, The Chinese University of Hong Kong. Dried seeds of H. mutabilis (420 g) were collected and extracted by homogenization in distilled water $(5 \mathrm{ml} / \mathrm{g}$ seeds). Following centrifugation at $20000 \times \mathrm{g}$ for $30 \mathrm{~min}$ at $4^{\circ} \mathrm{C}$, ammonium acetate buffer $(1 \mathrm{M}, \mathrm{pH} 4.6)$ was added to the supernatant until the final concentration of ammonium acetate reached $20 \mathrm{mM}$. The supernatant was then applied on a $5 \mathrm{~cm} \times 15 \mathrm{~cm}$ column of SP-Sepharose (GE Healthcare). Unadsorbed proteins were eluted with $20 \mathrm{mM}$ ammonium acetate buffer ( $\mathrm{pH}$ 4.6). Adsorbed proteins were eluted with $1 \mathrm{M} \mathrm{NaCl}$ added to the $20 \mathrm{mM}$ ammonium acetate buffer. The unadsorbed fraction was dialyzed, lyophylized, and then subjected to chromatography in $100 \mathrm{mM}$ ammonium acetate buffer $(\mathrm{pH} \mathrm{4.6)}$ on a Superdex 75 HR10/300 G/L column using an AKTA Purifier (GE Healthcare). The column had been calibrated with molecular mass markers, including Blue Dextran 2000 (to determine void volume), bovine serum albumin (67 kDa), ovalbumin (43 $\mathrm{kDa})$, chymotrypsinogen A (25 kDa), myoglobulin $(17.6 \mathrm{kDa})$, ribonuclease A $(13.7 \mathrm{kDa})$, aprotinin $(6.5$ $\mathrm{kDa})$, and vitamin B12 (1.3 kDa) (GE Healthcare). The first fraction was collected, lyophylized, and then subjected to chromatography in $100 \mathrm{mM}$ ammonium acetate buffer $(\mathrm{pH}$ 4.6) on a Superdex 200 HR 10/300 GL column using an AKTA Purifier. The column had been calibrated with molecular mass markers, including Blue Dextran 2000 (to determine void volume), thyroglobulin (669 $\mathrm{kDa})$, ferritin (440 $\mathrm{kDa})$, immunoglobulin $\mathrm{G}(150 \mathrm{kDa})$, bovine serum albumin $(67 \mathrm{kDa})$, $\beta$-lactoglobulin $(35 \mathrm{kDa})$, ribonuclease A (13.7 kDa), and aprotinin $(6.5 \mathrm{kDa})(\mathrm{GE}$ Healthcare). The first fraction represented purified lectin.

Molecular mass determination using sodium dodecyl sulfate/polyacrylamide gel electrophoresis, gel filtration, and N-terminal amino acid sequencing. The purified lectin $(30 \mu \mathrm{g})$, heated for $10 \mathrm{~min}$ or unheated, SDS and $\beta$-mercaptoethanol treated or untreated, was subjected to SDS/PAGE. The gel was stained with Coomassie Blue R-250. Gel filtration on a fast protein liquid chromatography Superdex 200 HR 10/300 GL column (GE Healthcare) using an AKTA Purifier (GE Healthcare) was conducted to determine the molecular mass of the lectin. The $H$. mutabilis lectin, IgG, and a mixture of the lectin and IgG were separately chromatographed on a Superdex $200 \mathrm{HR}$ 10/300 GL column to find out if the lectin has the same molecular mass as IgG. The Nterminal sequence of the lectin was determined as described in Lam et al. (2009).

Protein determination. Protein concentration was determined by Bradford reagent (dye-binding method) using bovine serum albumin as standard.

Assay for hemagglutinating activity. In the assay, a serial twofold dilution of the lectin solution $(1.28 \mathrm{mg} / \mathrm{ml})$ and concanavalin A (as positive control) in microtiter U-plates $(50 \mu \mathrm{l})$ was mixed with 50 $\mu \mathrm{l}$ of a $2 \%$ suspension of red blood cells (from rabbit, human (A, B, AB and $\mathrm{O}$ groups) and SpragueDawley rat) in phosphate-buffered saline ( $\mathrm{pH} 7.2)$ at $20^{\circ} \mathrm{C}$. The results were read after about $30 \mathrm{~min}$ when the blank had fully sedimented. One hemagglutination unit is the reciprocal of the highest dilution that is capable of inhibiting hemagglutination. Specific activity is the number of hemagglutination unit per milligram protein (Wong \& $\mathrm{Ng}$, 2006).

Inhibition of lectin-induced hemagglutination by divalent metal ions. The purified lectin was demetallized by treatment with EDTA before incubation in a water bath at room temperature for $15 \mathrm{~min}$ in the presence of one of the following salts: $\mathrm{ZnSO}_{4}$ $\mathrm{CaCl}_{2}, \mathrm{FeSO}_{4}, \mathrm{MgCl}_{2}, \mathrm{MgSO}_{4}, \mathrm{CuCl}_{2}$, and $\mathrm{CuSO}_{4}$ all at $5 \mathrm{mM}$. Hemagglutinating assay was then performed (Wong \& Ng, 2006).

Inhibition of lectin-induced hemagglutination by carbohydrates. The hemagglutinating inhibition tests were performed to investigate inhibition of lectin-induced hemagglutination by various carbohydrates (Wong \& Ng, 2006). The carbohydrates tested included galactonic acid, mannitol, D-glucosamine, D-xylose, sucrose, $\alpha$-lactose, D-fructose, D-mannose, D-glucuronic acid, D-glucose, D-sorbitol, and sialic acid. Serial twofold dilutions of sugar samples $(25 \mu \mathrm{l}$ of $400 \mathrm{mM}$ ) in phosphate-buffered saline were performed. All of the dilutions were mixed with $25 \mu \mathrm{l}$ of lectin with 16 hemagglutination units and incubated for $15 \mathrm{~min}$ at room temperature. Finally, $50 \mu \mathrm{l}$ of $2 \%$ rabbit erythrocyte suspension was added. The minimal concentrations of the aforementioned carbohydrates required to bring about inhibition of hemagglutination were recorded.

Effects of temperature and $\mathrm{pH}$ on lectin-induced hemagglutination. A solution of the purified lectin $(50 \mu \mathrm{g} / \mathrm{ml})$ was incubated at various temperatures $\left(4^{\circ} \mathrm{C}, 10-100^{\circ} \mathrm{C}\right)$ or in buffers at various $\mathrm{pH}$ values $(\mathrm{pH} 1-14)$ for $15 \mathrm{~min}$. It was then cooled down 
A

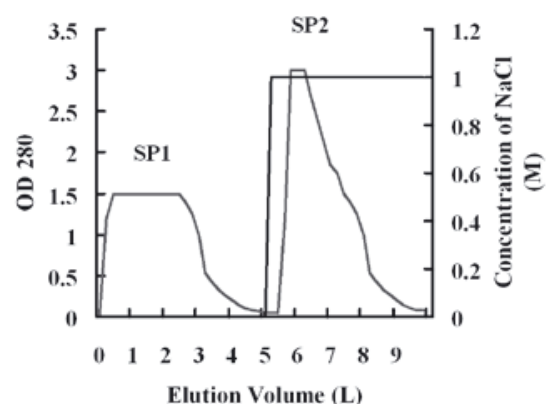

C

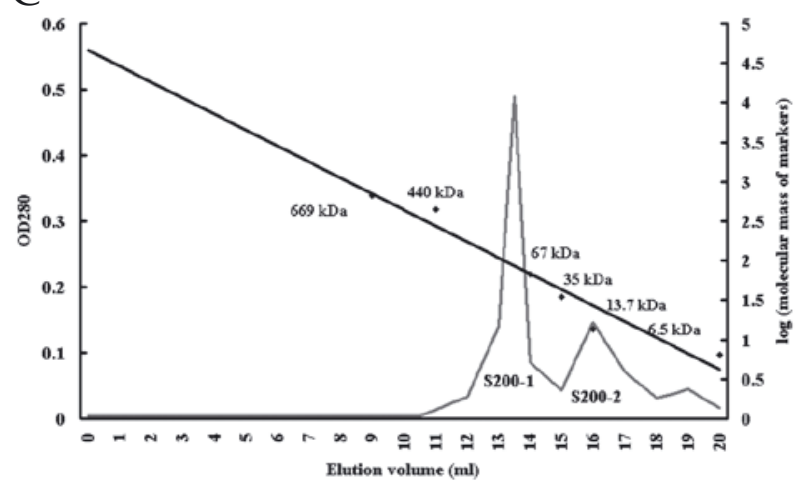

B

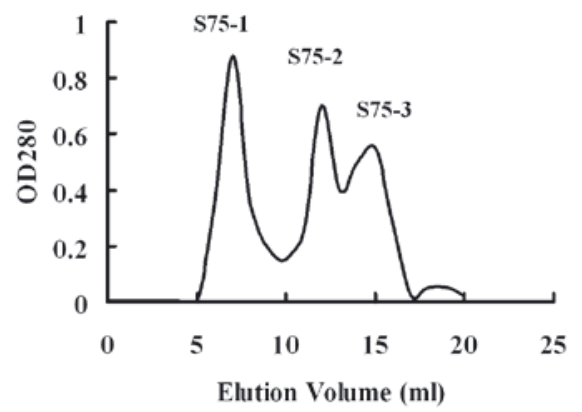

D

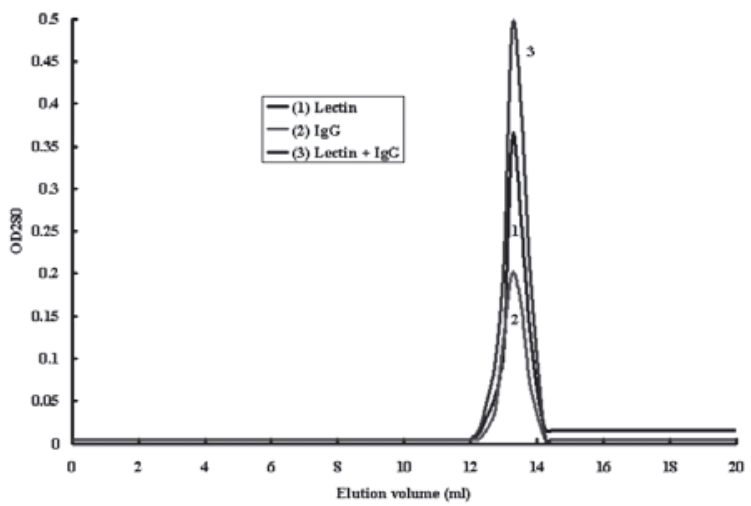

Figure 1. Purification of $\mathrm{H}$. mutabilis lectin.

A. Ion exchange chromatography of $H$. mutabilis extract on SP-Sepharose. The vertical line in the right half of the chromatogram indicates the use of $1 \mathrm{M} \mathrm{NaCl}$ to elute fractions SP2. Flow rate $=10 \mathrm{ml} / \mathrm{min}$. B. Gel filtration of SP1 fraction on Superdex 75. Flow rate $=0.5 \mathrm{ml} / \mathrm{min}$. C. Gel filtration of fraction S75-1 on Superdex 200. S200-1 represents purified H. mutabilis lectin. Flow rate $=0.5 \mathrm{ml} / \mathrm{min}$. D. Gel filtration of $H$. mutabilis lectin, $\operatorname{IgG}(150 \mathrm{kDa})$, and a mixture of the lectin and IgG separately on Superdex 200. Flow rate $=0.5 \mathrm{ml} / \mathrm{min}$.

to room temperature or neutralized to $\mathrm{pH} \mathrm{7,} \mathrm{imme-}$ diately before the hemagglutination assay (Wong \& $\mathrm{Ng}$, 2006).

Assay of antifungal activity. The assay for antifungal activity toward the pathogenic fungi Mycosphaerella arachidicola, Fusarium oxysporum, Helminthosporium maydis, Valsa mali and Rhizoctonia solani was carried out as described in Lam and $\mathrm{Ng}$ (2009). Nystatin (Sigma) was used as positive control.

Assay of HIV-1 reverse transcriptase inhibitory activity. The assay of lectin for the ability to inhibit HIV-1 reverse transcriptase was carried out by using an enzyme-linked immunosorbent assay kit from Boehringer Mannheim (Germany) as described in Lam and $\mathrm{Ng}$ (2009), in view of the observation that some lectins exhibit this activity (Lam et al., 2009). Capparis spinosa lectin was used as a positive control.

Assay of antiproliferative activity toward tumor cells. The assay of the antiproliferative activity of the lectin was carried out by testing its inhibitory effect on the growth of human hepatoma HepG2 cells and human breast cancer MCF-7 cells as described in Lam and $\mathrm{Ng}$ (2009). Doxorubicin and Rachycentron canadum lectin (Ngai \& Ng, 2007) were used as positive and negative control, respectively.

\section{RESULTS}

\section{Isolation of lectin}

The H. mutabilis seed extract was resolved on SP-Sepharose into two fractions of different sizes, an unadsorbed fraction SP1 with hemagglutinating activity and an adsorbed fraction SP2 without hemagglutinating activity (Fig. 1A). Fraction SP1 was dialyzed, and lyophylized before separation on Superdex 75 into three major fractions. S75-1, with hemagglutinating activity eluted in the void volume, and two larger fractions, S752 and S75-3, without such activity (Fig. 1B). Fraction S75-1 was lyophylized before being separated on Superdex 200 into two major fractions, S200-1, a larger fraction with hemagglutinating activity, and a smaller fraction S200-2 without activity (Fig. 1C). The lectin, $\operatorname{IgG}$, and a mixture of the lectin and IgG were eluted from the Superdex $200 \mathrm{HR}$ 10/300 GL column with the same elution volume (Fig. 1D) indicating that the lectin has the same molecular mass as IgG (150 kDa). Fraction S200-1, with a native molecular mass of $150 \mathrm{kDa}$, represented purified lectin as evidenced by a single 24$\mathrm{kDa}$ band in SDS/PAGE, indicating that the lectin was a hexamer (Fig. 2B). An SDS/PAGE analysis of crude extract was performed indicating the lectin 

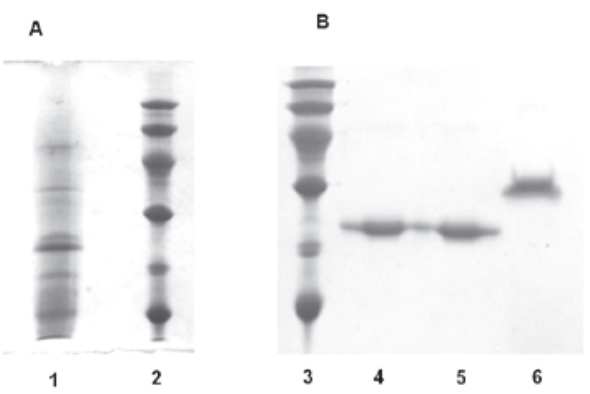

Figure 2. SDS of subsequent steps of $H$. mutabilis lectin purification.

A. Lane 1: H. mutabilis crude extract. Lane 2: molecular mass markers including phosphorylase $\mathrm{b}(94 \mathrm{kDa})$, bovine serum albumin (67 kDa), ovalbumin (43 kDa), carbonic anhydrase $(30 \mathrm{kDa})$, soybean trypsin inhibitor $(20 \mathrm{kDa})$, and $\alpha$-lactalbumin $(14.4 \mathrm{kDa})$. B. Lane 3: molecular mass markers. Lane 4: Fraction S200-1 (30 $\mu$ g) representing $H$. mutabilis lectin (heated, SDS/ $\beta$-mercaptoethanol treated). Lane 5: unheated purified lectin $(30 \mu \mathrm{g})$ treated with SDS/ $\beta$-mercaptoethanol. Lane 6: purified lectin $(30 \mu \mathrm{g})$ without heat or SDS $/ \beta$-mercaptoethanol treatment.

is one of the major protein components (Fig. 2A). Unheated, SDS/ $\beta$-mercaptoethanol treated purified lectin showed the same electrophoretic mobility as

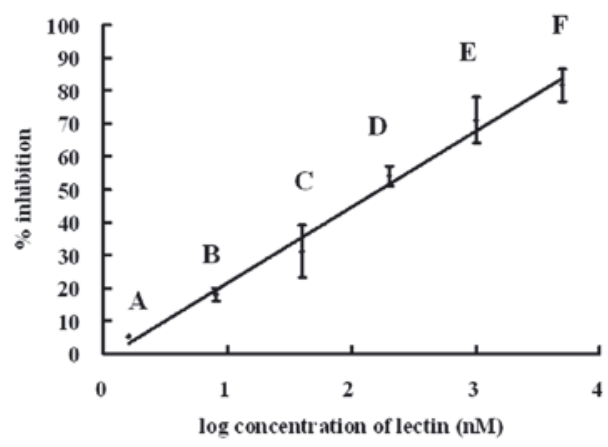

Figure 3. Inhibition of $\mathrm{HIV}-1$ reverse transcriptase by H. mutabilis lectin.

Percent inhibition compared to a control without the protein is indicated. Values are expressed as the mean \pm S.D. $(\mathrm{N}=3)$. Different letters on the same straight line indicate statistically significant difference $(P<0.05)$ between the data upon analysis using ANOVA followed by Duncan's multiple range test.

the following sugars were tested up to $100 \mathrm{mM}$ : D-glucosamine, mannitol, D-xylose, sucrose, D-fucose, D-raffinose, $\alpha$-lactose, $\mathrm{D}$-fructose, L-arabinose, D-galacturonic acid, D-galactose, D-mannose, D-glucuronic acid, D-glucose, D-sorbitol, and sialic acid. The hemagglutinating activity of the lectin was stable in the $\mathrm{pH}$ range $4-7$. About $50 \%$ activity was retained at $\mathrm{pH} 3$ and $\mathrm{pH} 8-9$. The activity was completely eliminated at $\mathrm{pH}$ $1-2$, and 10-14. The activity was stable

the heated, SDS $/ \beta$-mercaptoethanol treated purified lectin in SDS/PAGE, while the electrophoretic mobility of unheated, SDS/ $\beta$-mercaptoethanol untreated purified lectin was lower (Fig. 2B). The H. mutabilis lectin was obtained with a specific hemagglutinating activity of $4000 \mathrm{unit} / \mathrm{mg}$ for rabbit blood. There was no hemagglutinating activity for rat blood and human blood. The lectin yield was $17 \mathrm{mg}$ from $420 \mathrm{~g}$ seeds. The recovery of hemagglutinating activity was $34 \%$ (Table 1 ). Its $\mathrm{N}$-terminal sequence, ACVAPLDEAACAAAK, resembled none of the lectins reported so far. The homogeneity of the lectin was disclosed by a single peak in each Edman degradation cycle during amino acid sequencing.

\section{Hemagglutinating activity of lectin}

The hemagglutinating activity of the lectin could be inhibited by galactonic acid at 25 $\mathrm{mM}$ concentration There was no inhibition when in the temperature range $0-50^{\circ} \mathrm{C}$, reduced to half at $60^{\circ} \mathrm{C}$, and destroyed at $70^{\circ} \mathrm{C}$. Of the various salts tested, only manganese chloride and manganese sulfate restored the activity of the lectin (not shown).

\section{Other biological activities of isolated lectin}

The lectin inhibited HIV-1 reverse transcriptase with an $\mathrm{IC}_{50}$ of $200 \mathrm{nM}$ (Fig. 3). There was no inhibitory effect on mycelial growth of Mycosphaerella arachidicola, Fusarium oxysporum, Helminthosporium maydis, Valsa mali, or Rhizoctonia solani at $100 \mu \mathrm{M}$ lectin. The lectin exhibited weak antiproliferative activity toward tumor cells. There was about $50 \%$ growth inhibition of MCF-7 cells and about $40 \%$ growth inhibition of HepG2 cells when the cells were treated with $100 \mu \mathrm{M}$ lectin. Rachycentron canadum lectin showed no antiproliferative effect. By comparison, the positive control doxorubicin exhibited an antiproliferative activ- 
ity toward these tumor cells with an $\mathrm{IC}_{50}$ of $5 \mu \mathrm{M}$ and $10 \mu \mathrm{M}$, respectively.

\section{DISCUSSION}

To the best of our knowledge, there are only seven hexameric lectins reported in the literature, including those from Axinella corrugata (Dresch et al., 2008), Ganoderma lucidum (Thakur et al., 2007), Helix pomatia (Sanchez et al., 2006), Ctenopharyngodon idellus (Lam \& Ng, 2002), Trimeresurus albolabris venom (Du et al., 2002), Lactarius rufus (Panchak \& Antoniuk, 2007), and Araucaria angustifolia lectin (Datta et al., 1991). Even fewer examples of octameric lectins, e.g. Anguilla japonica lectin (Mistry et al., 2001), and only a single decameric lectin purified from Araucaria angustifolia (Datta et al., 1991) have been reported. All hexameric lectins reported are stable at around $\mathrm{pH} 4$ to $\mathrm{pH} 8$ and around $50^{\circ} \mathrm{C}$ to $65^{\circ} \mathrm{C}$. The $\mathrm{H}$. $m u-$ tabilis lectin resembles them in $\mathrm{pH}$ stability and thermostability.

Many lectins manifest binding to one sugar (Sultan et al., 2009) or two sugars (Devi et al., 2009). In some cases, lectins can be inhibited by more than two sugars (Wang et al., 2000; 2002; Lam et al., 2009). It is worth noting that the H. mutabilis lectin is the first galactonic acid-binding lectin reported to date. This lectin is capable of agglutinating rabbit, but not rat or human red blood cells. As yet, there is no evidence that galactonic acid is present on the surface of rabbit erythrocytes. Thus, the lectin may also recognize some other sugars on the surface of rabbit erythrocytes that have not been tested in this study.

Some lectins are adsorbed on anion-exchangers (Sultan et al., 2009) or cation-exchangers (Sharma et al., 2009). Some are adsorbed on both types of exchangers ( $\mathrm{Xu}$ et al., 2007). The H. mutabilis lectin is not adsorbed on a cation exchanger (SP-Sepharose), and it is tightly bound and cannot be dislodged from anion-exchangers by $2 \mathrm{M} \mathrm{NaCl}$ in $\mathrm{pH} 4.6$ ammonium acetate buffer (DEAE-cellulose and Q-Sepharose). The purification scheme mainly depends on gel filtration, which is different from the previously reported lectins.

Information pertaining to the biological activities of hexameric lectins is meager. The A. corrugata lectin displays a chemotactic effect on rat neutrophiles (Dresch et al., 2008). The C. idellus lectin is mitogenic toward murine splenocytes and peritoneal exudate cells (Lam \& Ng, 2002). There are no reports on the biological activities of other hexameric, octameric and decameric lectins.

The H. mutabilis lectin potently inhibited HIV1 reverse transcriptase with an $\mathrm{IC}_{50}$ of $0.2 \mu \mathrm{M}$. Its activity is much stronger than that of other lectins which display an $\mathrm{IC}_{50}$ of $3-35 \mu \mathrm{M}$, including pinto bean lectin (Wong et al., 2006) and Xerocomus spadiceus lectin (Liu et al., 2004). Its potency is similar to that of C. spinosa lectin (Lam et al., 2009). The mechanism of inhibition is probably protein-protein interaction, HIV-1 protease inhibits the homologous reverse transcriptase by protein-protein interaction (Böttcher \& Grosse, 1997).

Not all lectins showed antiproliferative activity on tumor cells, e.g. Rachycentron canadum lectin (Ngai \& Ng, 2007). Some lectins exhibit antiproliferative or antitumor activity ( $\mathrm{Xu}$ et al., 2007). The $H$. mutabilis lectin at $100 \mu \mathrm{M}$ concentration produced only about $50 \%$ inhibition of proliferation in HepG2 and MCF-7 cells. There are only a small number of reports on antifungal lectins, e.g. Artocarpus genus lectin can inhibit Fusarium moniliforme and Saccharomyces cerevisiae (Trindade et al., 2006). The H. mutabilis lectin is similar to most other lectins that are devoid of antifungal activity.

The N-terminal amino acid sequence of H. mutabilis lectin is ACVAPLDEAACAAAK. To date, no lectins have been reported with this partial sequence.

The subunits of a protein in the quaternary structure must be in non-covalent association (Devlin, 1997). The subunits in dimeric or tetrameric leguminous lectins comprise a flat six-stranded $\beta$ sheet and a curved seven-stranded $\beta$-sheet linked by loops of different lengths (Banerjee et al., 1994). The monomer of hexameric Helix pomatia agglutinin is composed of a six-stranded antiparallel $\beta$-sandwich. The $\beta$-strands are linked and produce a hairpin at one extremity of the $\beta$-sandwich (Sanchez et al., 2006). The subunit arrangement of $H$. mutabilis lectin probably resembles that of hexameric Helix pomatia agglutinin. SDS/ $\beta$-mercaptoethanol treatment resulted in a higher electrophoretic mobility of the lectin indicating its multimeric nature.

All in all, the reported $H$. mutabilis lectin is unique in its high molecular mass, multimeric nature, sugar specificity, novel $\mathrm{N}$-terminal amino acid sequence and extremely strong adsorption to anionic exchangers including DEAE-cellulose and Q-Sepharose.

\section{REFERENCES}

Banerjee R, Mande SC, Ganesh V, Das K, Dhanaraj V, Mahanta SK, Suguna K, Surolia A, Vijayan M (1994) Crystal structure of peanut lectin, a protein with an unusual quaternary structure. Proc Natl Acad Sci USA 91: 227-231.

Böttcher M, Grosse F (1997) HIV-1 protease inhibits its homologous reverse transcriptase by protein-protein interaction. Nucleic Acids Res 25: 1709-1714.

Datta PK, Figueroa MO, Lajolo FM (1991) Purification and characterization of two major lectins from Araucaria 
brasiliensis syn. Araucaria angustifolia Seeds (Pinhão). Plant Physiol 97: 856-862.

De Hoff PL, Brill LM, Hirsch AM (2009) Plant lectins: the ties that bind in root symbiosis and plant defense. Mol Genet Genomics 282: 1-15.

Devi SK, Devi LI, Singh LR (2009) Purification and characterization of a new dimeric mannose/glucose-binding isolectin from Vicia tetrasperma (L.) Schreber. Prep Biochem Biotechnol 39: 57-71.

Devlin TM (1997) Textbook of biochemistry: with clinical correlations. 4 th edn, $\mathrm{p} 48$. Wiley-Liss, Inc.

Dresch RR, Zanetti GD, Lerner CB, Mothes B, Trindade VM, Henriques AT, Vozári-Hampe MM (2008) ACL-I, a lectin from the marine sponge Axinella corrugata: isolation, characterization and chemotactic activity Comp Biochem Physiol C Toxicol Pharmacol 148: 23-30.

Du XY, Magnenat E, Wells TN, Clemetson KJ (2002) Alboluxin, a snake C-type lectin from Trimeresurus albolabris venom is a potent platelet agonist acting via GPIb and GPVI. Thromb Haemost 87: 692-698.

Jin S, Cheng Y, Reid S, Li M, Wang B (2009) Carbohydrate recognition by boronolectins, small molecules, and lectins. Med Res Rev (Epub ahead of print).

Kholkute SD, Mudgal V, Udupa KN (1977) Studies on the antifertility potentiality of Hibiscus rosa sinensis. Parts of medicinal value; selection of species and seasonal variations. Planta Med 31: 35-39.

Lam YW, Ng TB (2002) Purification and characterization of a rhamnose-binding lectin with immunoenhancing activity from grass carp (Ctenopharyngodon idellus) ovaries. Protein Expr Purif 26: 378-385.

Lam SK, Han QF, Ng TB (2009) Isolation and characterization of a lectin with potentially exploitable activities from caper (Capparis spinosa) seeds. Biosci Rep 29: 293-299.

Lam SK, Ng TB (2009) A protein with antiproliferative, antifungal and HIV-1 reverse transcriptase inhibitory activities from caper (Capparis spinosa) seeds. Phytomedicine 16: 444-450.

Leung EH, Wong JH, Ng TB (2008) Concurrent purification of two defense proteins from French bean seeds: a defensin-like antifungal peptide and a hemagglutinin. $J$ Pept Sci 14: 349-353.

Liu Q, Wang H, Ng TB (2004) Isolation and characterization of a novel lectin from the wild mushroom Xerocomus spadiceus. Peptides 25: 7-10.

Liu J, Xu X, Liu J, Balzarini J, Luo Y, Kong Y, Li J, Chen F, Van Damme E, Bao J (2007) A novel tetrameric lectin from Lycoris aurea with four mannose binding sites per monomer. Acta Biochim Polon 54: 159-166.

Mistry AC, Honda S, Hirose S (2001) Structure, properties and enhanced expression of galactose-binding C-type lectins in mucous cells of gills from freshwater Japanese eels (Anguilla japonica). Biochem J 360: 107-115.

Ngai PH, Ng TB (2007) A mannose-specific tetrameric lectin with mitogenic and antibacterial activities from the ovary of a teleost, the cobia (Rachycentron canadum). Appl Microbiol Biotechnol 74: 433-438.

Panchak LV, Antoniuk VO (2007) Purification of lectin from fruiting bodies of Lactarius rufus (Scop.: Fr.) Fr. and its carbohydrate specificity. Ukr Biokhim Zh 79: $123-128$.
Sanchez JF, Lescar J, Chazalet V, Audfray A, Gagnon J, Alvarez R, Breton C, Imberty A, Mitchell EP (2006) Biochemical and structural analysis of Helix pomatia agglutinin. A hexameric lectin with a novel fold. J Biol Chem 281: 20171-20180.

Sharma A, Ng TB, Wong JH, Lin P (2009) Purification and characterization of a lectin from Phaseolus vulgaris $c v$. (Anasazi beans). J Biomed Biotechnol (Epud ahead of print).

Sultan NA, Kavitha M, Swamy NJ (2009) Purification and physicochemical characterization of two galactose-specific isolectins from the seeds of Trichosanthes cordata. IUBMB Life 61: 457-469.

Thakur A, Rana M, Lakhanpal TN, Ahmad A, Khan M (2007) Purification and characterization of lectin from fruiting body of Ganoderma lucidum: lectin from Ganoderma lucidum. Biochim Biophys Acta 1770: 1404-1412.

Trindade MB, Lopes JL, Soares-Costa A, Monteiro-Moreira AC, Moreira RA, Oliva ML, Beltramini LM (2006) Structural characterization of novel chitin-binding lectins from the genus Artocarpus and their antifungal activity. Biochim Biophys Acta 1764: 146-152.

Wang HX, Ng TB (2006) Concurrent isolation of a Kunitztype trypsin inhibitor with antifungal activity and a novel lectin from Pseudostellaria heterophylla roots. Biochem Biophys Res Commun 342: 349-353.

Wang H, Gao J, Ng TB (2000) A new lectin with highly potent antihepatoma and antisarcoma activities from the oyster mushroom Pleurotus ostreatus. Biochem Biophys Res Commun 275: 810-816.

Wang H, Ng TB, Liu Q (2002) Isolation of a new heterodimeric lectin with mitogenic activity from fruiting bodies of the mushroom Agrocybe cylindracea. Life Sci 70: 877-885.

Wong JH, NgTB (2006) Isolation and characterization of a glucose/mannose-specific lectin with stimulatory effect on nitric oxide production by macrophages from the emperor banana. Int J Biochem Cell Biol 38: 234-243.

Wong JH, Wong CC, Ng TB (2006) Purification and characterization of a galactose-specific lectin with mitogenic activity from pinto beans. Biochim Biophys Acta 1760: 808-813.

Xu X, Wu C, Liu X, Luo Y, Li J, Zhao X, Damme EV, Bao J (2007) Purification and characterization of a mannosebinding lectin from the rhizomes of Aspidistra elatior Blume with antiproliferative activity. Acta Biochim Biophys Sin (Shanghai) 39: 507-519.

Yan Q, Jiang Z, Yang S, Deng W, Han L (2005) A novel homodimeric lectin from Astragalus mongholicus with antifungal activity. Arch Biochem Biophys 442: 72-81.

Yang X, Tang D, Xu D, Wang X, Pan G (2004) Characters of greening tree species in heavy metal pollution protection in Shanghai. Ying Yong Sheng Tai Xue Bao 4: 687-690.

Yeh PY, Ling WF, Takasaka R (1958) Pigments in the flower of fu-yong (Hibiscus mutabilis L.). Science 128: 312.

Zheng MS (1989) An experimental study of the anti-HSVII action of 500 herbal drugs. J Tradit Chin Med 9: 113116. 